\title{
Production of mannan-degrading enzymes from Aspergillus niger and Sclerotium rolfsii using palm kernel cake as carbon source.
}

\begin{abstract}
The aim of this study is to produce and profile the mannan-degrading enzymes from local fungal isolates by submerged fermentation and saccharification of PKC. Results showed that Aspergillus niger and Sclerotium rolfsii can produce mannan-degrading enzymes. The fungi were grown in submerged fermentation of PKC to produce mannan-degrading enzymes. The highest alpha-galactosidase was obtained on day 13 of fermentation $(0.128 \mathrm{U}$ mL-1) when using A. niger and on day $18(0.126 \mathrm{U} \mathrm{mL}-1)$ when using S. rolfsii. Analysis also showed that enzyme activities for beta-mannanase using S. rolfsii were the highest at day 17 (3.166 U $\mathrm{mL}-1)$ and for A. niger (2.482 $\mathrm{U} \mathrm{mL}-1)$ at day 8. Meanwhile the highest beta-mannosidase were obtained at day 16 for A. niger $(0.128 \mathrm{U} \mathrm{mL}-1)$ and for S. rolfsii at day $16(0.116 \mathrm{U} \mathrm{mL}-$ $1)$.
\end{abstract}

Keyword: Mannan-degrading enzymes; Aspergillus niger; Sclerotium rolfsii; Palm kernel cake (PKC); Carbon source. 